\title{
A Study of Students' Motivation in Using the Mobile Arc Welding Learning App
}

https://doi.org/10.3991/ijim.v13i10.11305

\author{
Farhatun Najwa Rusli ${ }^{(凶)}$, Abdul Nasir Zulkifli, \\ Mohd. Nizam bin Saad, Yussalita Md. Yussop \\ Universiti Utara, Kedah, Malaysia \\ najwarusli.18@gmail.com
}

\begin{abstract}
Welding is an introductory core subject that is taught in every mechanical engineering programs at all polytechnics in Malaysia. Normally students will learn the theoretical concepts of welding in the class followed by instruction-based training in the workshop. However, students have difficulty to follow everything that has been taught in the class in a limited time. Welding is dangerous for beginners and the welding environments are harmful and injurious to the health. In this paper, we introduce Mobile Arc Welding Learning (MAWL) app, a new approach for learning arc welding that incorporates mobile technology and enhanced with augmented reality (AR). The aim of this app is to enhance the contents used in arc welding learning materials used in the conventional learning by visualizing the information through the use of text, images, videos and 3D models. The MAWL app covers topics related to safety in welding, components of welding and steps in welding. The students can use the app to learn about welding on their own anytime and anywhere. The potential of using the MAWL app for welding learning among the polytechnic students has been investigated, specifically focusing on ease of use, learn ability, satisfaction, usefulness, motivation and engagement. The results of the evaluation indicate that the users strongly agreed on ease of use, learn ability, satisfaction, usefulness and motivation, while they agreed on engagement. These prove that the MAWL app has the potential to contribute to students' welding learning through interactive and accessible information that satisfies them.
\end{abstract}

Keywords-Mobile Learning, Augmented Reality, Arc Welding Learning, TVET, User Evaluation.

\section{$1 \quad$ Introduction}

Technical and Vocational Education and Training (TVET) includes general education, technologies study of practical skills, attitudes, and knowledge relating to jobs in different economic sectors (Tripney \& Hombrados, 2013). Under the 2019 Budget, the Malaysian Government provided about RM30 million for TVET and RM20 million for Bootcamp Program related to TVET in order to enhance youth competence (Astro Awani, 2018; Berita Harian Online, 2018). Furthermore, the 
Minister of Education, Dr. Maszlee Malik said the allocation provided for TVET is important because the government found that those with skills potentially got a better job (Free Malaysia Today, 2018). TVET is expected to address the economic, social and environmental demands by helping young people and adults to develop their abilities that are needed for their job and entrepreneurship (The Star Online, 2016). According to the Malaysia Education Blueprint 2013-2025 Preliminary Report, vocational education provides students for career that requires expertise in a particular technique and these career consisting of technical or vocational skills, while technical education prepares students to higher levels of education (Kementerian Pendidikan Malaysia, 2012). Hence, Polytechnic, Higher Learning Institutions and Community Colleges provided TVET education for students where they can learn and train by doing lots of hands-on works to hone their skills.

In Malaysia, Polytechnic is one of many higher educational institutions responsible for providing TVET programs. Currently there are 34 polytechnics throughout Malaysia and they offer various levels of education ranging from certificate up to degree programs. For students enrolling in the Mechanical Engineering programs at any Polytechnics in Malaysia, they have to take various courses related to the field including theoretical and practical trainings which include welding as an introductory core subject. In the early stage, the students will learn the basic of welding which include gas and arc. While in the advanced stage, they will learn to use more advanced welding techniques that include; tungsten inert gas (TIG) and metal inert gas (MIG). Normally the students are trained in welding through the conventional methods which include PowerPoint slides, paper-based lecture notes and instruction based training (IBT). IBT guides students in using the welding equipment through step-by-step explanation about the procedures in the workshop. Prior to IBT, normally the explanation is done in the class. However, this approach results in some of the students to be unable to take part in some of the lessons or miss the training material provided by the lecturer. In addition, the common problem that dwells around the current learning environment is that the students have difficulty to follow everything that has been taught in the class in a limited time (Mahamad et al., 2010). If the students are not able to properly follow all the steps involved in the welding process, this might jeopardize the process as well as their safety. This is because welding training is dangerous for beginners because of lack of skills, time-consuming and requires proper equipment, tools and materials (Hashimoto, 2015). The welding working environments are harmful and injurious to the health with strong arc light, sparks, fumes, and ultraviolet ray (Wang et al., 2006). For such situation, it is helpful if the students are well prepared in terms of the required information needed prior to IBT. As such, the students need to explore alternative ways to fully understand and be able to follow the steps on their own.

There are various supplementary learning approaches for welding and that includes; books, websites, and YouTube. Hence, an innovative approach of learning is required to allow the students to be able to follow step-by-step instructions on the operation of the welding equipment. This is because, it is important for students to have the technological knowledge and experience in welding, hand skills and training in welding joints (Oz et al., 2012). This will ensure that the welding process is done 
correctly and also the safety of the students is taken care off. The new learning approach must also provide comprehensive information about the welding process in order to facilitate the students during revision.

Mobile technology has been one of the most important elements to most people in their every day's life. It is not being used just for communication alone, but its usage has grown and expanded whenever various applications have been developed specifically for it. Mobile technology has been used extensively in education (Sanusi et al., 2018; Shamsuddin et al., 2018; Yahya, et al., 2018), healthcare (Al-Hasnawi et al., 2016; Qasim et al., 2018a; Qasim et al., 2018b; Qasim et al., 2015), advertising (Idris et al., 2018; Zulkifli et al., 2016; Hadiwardoyo, et al., 2018) and many more.

This paper introduces Mobile Arc Welding Learning (MAWL) app, a welding learning approach through the use of mobile learning application implemented with $\mathrm{AR}$ and also examines students' perception on using this app in terms of ease of use, engagement, learn ability, satisfaction, usefulness and motivation. It is structured as follows. In section II, we discuss the literature review on Technical and Vocational Education and Training (TVET), Mobile Learning, Augmented Reality and Welding. Motivation and MAWL App. In section III, we describe briefly on the MAWL app. The methodology is presented in section IV, while section V discusses the results and finally, the conclusion is established in section VI.

\section{$2 \quad$ Literature Review}

In this section we discuss some of the important topics of past literatures that are related to the study which include; Technical and Vocational Education and Training, Mobile learning and Augmented Reality.

\subsection{Technical and vocational education and training}

TVET refers to those aspects of the educational process involving, in addition to general education, the study of technologies and related sciences, and the acquisition of practical skills, attitudes, understanding and knowledge relating to occupations in various sectors of economic and social life (UNESCO, 2004). TVET is defined as the building skills needed for a particular kind of occupation or job (Zelloth, 2014) whereby its main goal is to personalize and individualize instructions (Natarajan, 2016). TVET develops ways of learning and the acquisition of attitudes that facilitate success in the workplace (Ngure, 2013). TVET is provided by public and private sectors aimed at making the students gain practical knowledge and technical knowhow which are essential for securing employment in a specific field, which includes trade or group of vocations (Nyerere, 2009). Malaysia has declared 2017 as the Year of TVET in an effort to achieve a high-income nation status by 2020 (Astro Awani, 2017; Leong, 2011; The Sundaily, 2015). The labour demand is expected to increase to 3.3 million of which 1.3 million are TVET graduates by 2020 (Ismail \& Abiddin, 2014). Malaysia needs knowledgeable and skilled workforce to support and drive the economy. Currently, with the growth of labour at $2 \%$ per annum and if no drastic 
action taken by the Malaysian government in producing marketable TVET graduates, Malaysia will not be able to meet the demand for human capital with an estimated shortage of 350,000 by 2020 (Economic Transformation Plan, 2014).

\subsection{Mobile learning}

Now people spend a lot of their time with their mobile devices. Mobile devices are not limited just to making calls, SMS, e-mail, and WhatsApp, but they are also used for a plethora of applications. This development has led to a new form of learning through the use of mobile technology in education that has changed the way people think and process information which is known as mobile learning (Ge \& Ifenthaler, 2018). Mobile learning is the use of simple devices like smartphones, tablets, iPods, and PDAs for the purpose of learning and education (Abachi \& Muhammad, 2014). Mobile learning is able to meet the basic needs of learning as it provides an engaging learning environment for students (Carvalho et al., 2015; Connolly et al., 2012; Crookall, 2010; Sandholtz, 1997). Mobile learning has several features in learners' support which include; mobility, freedom and self-study, availability, facilitating student and teacher interaction, and information sharing (Bidin \& Ziden, 2013; Ozdamli \& Cavus, 2011; Viberg \& Grönlund, 2013). Mobile learning based on ubiquitous technology may be considered as part of a progress towards discovery based learning (Lugmayr, 2017; Wouters, 2013). The use of mobile learning can enhance students' learning interest (Ebner \& Holzinger, 2007) and increase their motivation (Burguillo, 2010; Dickey, 2011). Mobile learning technology has the potential to enhance the knowledge, skills and performance of the students through informal learning (Hwang \& Wu, 2012; Camilleri \& Camilleri, 2017). Mobile learning has positive impact on students of higher learning institutions in terms of their attitudes towards learning and their perceptions in accessing the learning activities (Abachi \& Muhammad 2014; O'bannon and Thomas 2014). Mobile learning can overcome the limited face-to-face time that lecturers have with students in a classroom (Suprianto et al., 2019). It also provides benefits not only to students but also lecturers whereby they can access the learning materials anytime and anywhere and the students can get additional teaching and learning materials not limited during class hours only (Suprianto et al., 2019). However, the use of mobile learning in TVET education is still lagging behind.

\subsection{Augmented reality}

Augmented Reality (AR) is one of the technologies that can be applied in education that helps students to learn more effectively and increase retention of knowledge (Billinghurst \& Dünser, 2012). AR is a combination of real world and digital data (Siltanen, 2012). AR superimposes virtual objects and real images, thus producing a composite view. By doing so it enhances the reality of an image that is viewed through a device such as a smartphone (McMillan, Flood, \& Glaeser, 2017). Virtual objects in the form of text, image, video, and 3D model can be superimposed onto the real image which can be manipulated by the user via physical manipulation 
(Billinghurst \& Dünser, 2012). AR involves the use of a camera to capture the image, recognizing by marker and adding virtual elements by the software and the projection of these elements actually associate virtual and real elements in an augmented reality time (Okimoto et al., 2015). AR consists of marker-based AR and location-based AR. Marker-based AR requires specific image to register the $3 \mathrm{D}$ object's position on the real-world image (Cheng \& Tsai, 2013). Location based-AR uses Global Positioning System (GPS) data where location is identified and then overlay computer-generated information onto the real image of the mobile device (Cheng \& Tsai, 2013). AR is suitable for use in various educational environments and many AR applications have been successfully developed to enhance learning in language (Ramya \& Madhumathi, 2017; Yang \& Mei, 2018), science (Gopalan et al., 2015; Gopalan et al., 2018) and TVET (Sing \& Annie, 2018; Ali, Johari, \& Omar, 2017). AR enables learners to engage and motivate in exploring materials from diverse perspectives that are impossible in the real world (Kerawalla et al., 2006). According to (Lee, 2012), some researchers have suggested that virtual and augmented reality can increase motivation of learner in learning and improve their educational realism-based practices. The use of AR can increase motivation, attention, satisfaction and concentration to learn something in the education environments (Diegmann, 2015).

\section{Mobile ARC Welding Learning (MAWL) App}

The Mobile Arc Learning Welding (MAWL) app has been specifically developed for the Mechanical Engineering students of Polytechnic Tuanku Syed Sirajuddin who were learning arc welding as one of their core subjects. The app has been developed as a supplement to the conventional learning approach in the class prior to the IBT in the workshop. This app provides additional information related to arc welding through the use of multimedia elements comprising of texts, images, videos and also 3D models. In addition, the app has been enhanced with augmented reality aimed at attracting students to use the app in welding-related learning. Meanwhile, the MAWL app is meant to be used by the students whenever they need to learn on their own in the absence of the lecturer at home or outside the class. Through the use of the app, the students are able to access a more comprehensive as well as interactive information regarding safety in welding, components of welding and steps in welding as shown in Fig. 1. The Safety in Welding button enables user to read information pertaining to the protective equipment as shown in Fig. 2, precautions that should be taken before and after welding and also the potential hazards while welding. The Components of Welding button provides the equipment for welding that include; power source AC/DC, electrode holder and cables, welder protection and tools as shown in Fig. 3. The user can click on the equipment in order to display more detail information pertaining to it. Lastly, the Steps in Welding button provides information regarding the steps to be taken before starting the welding process, steps in starting the arc welding process and welding defect as shown in Fig. 4. For each step, detail information in the form of text, image and video is provided. In this section also, augmented reality is being implemented to make the app more interactive to user. 

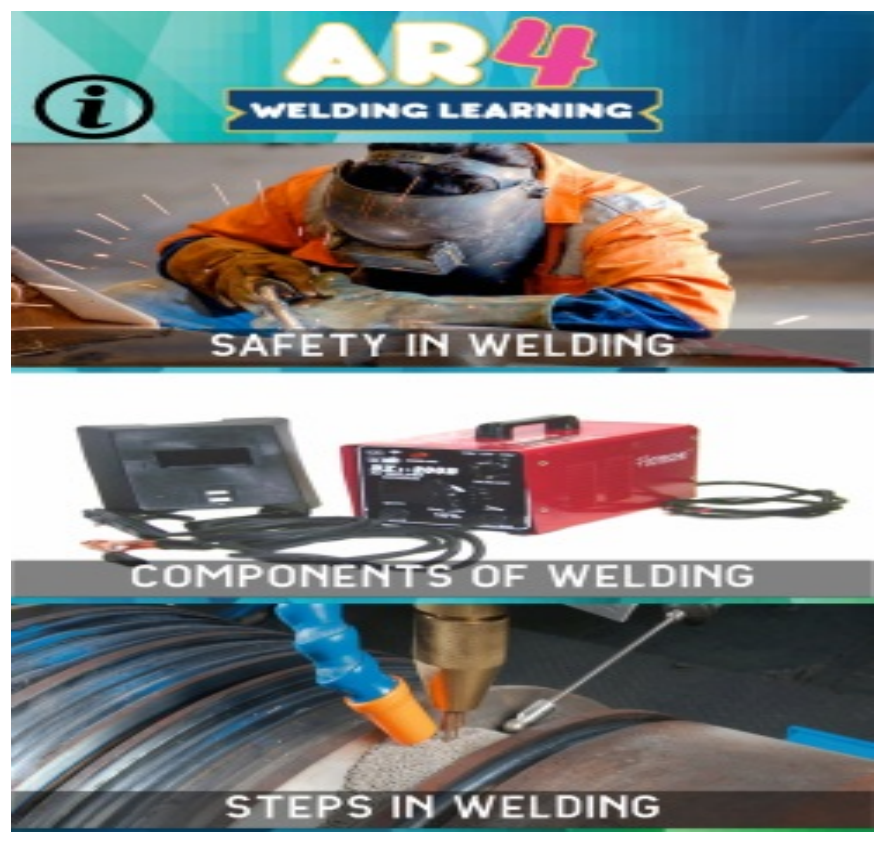

Fig. 1. The main interface of the MAWL app
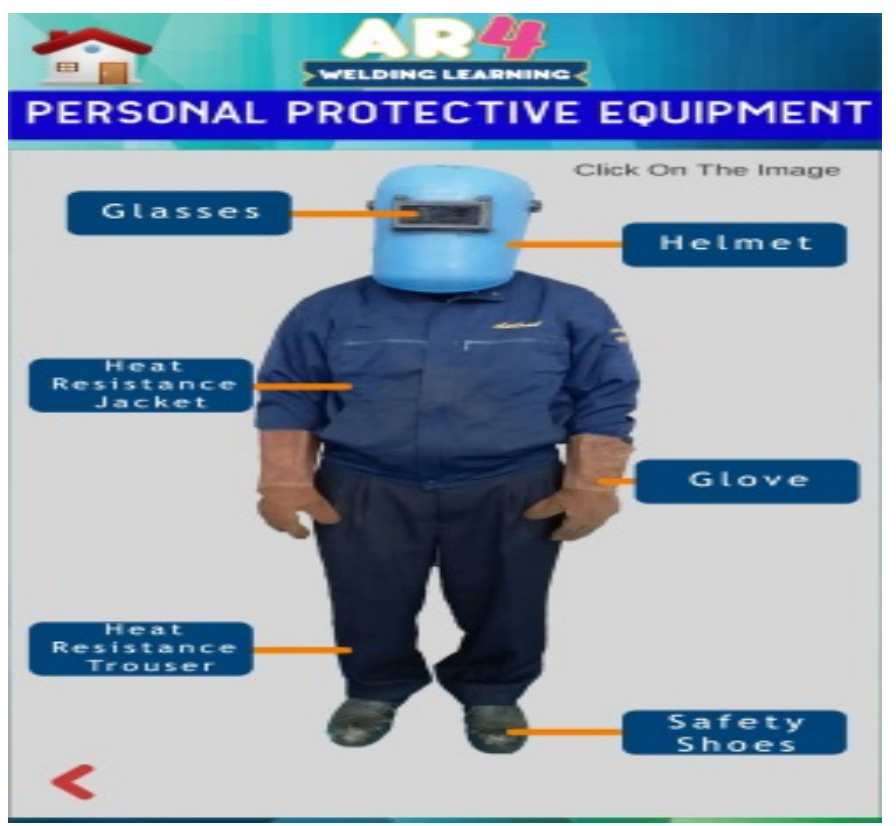

Fig. 2. The interface for protective equipment 


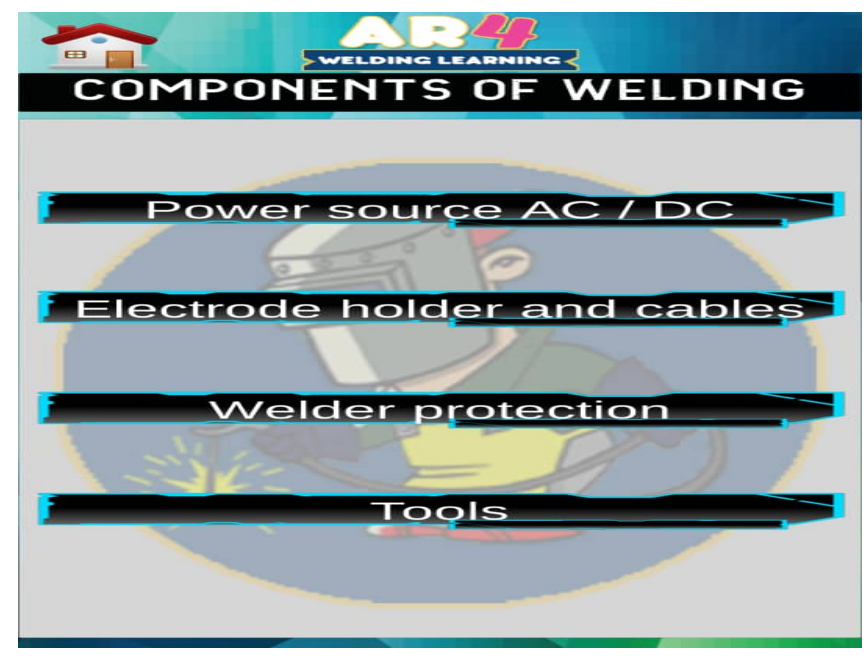

Fig. 3. The interface for components of welding

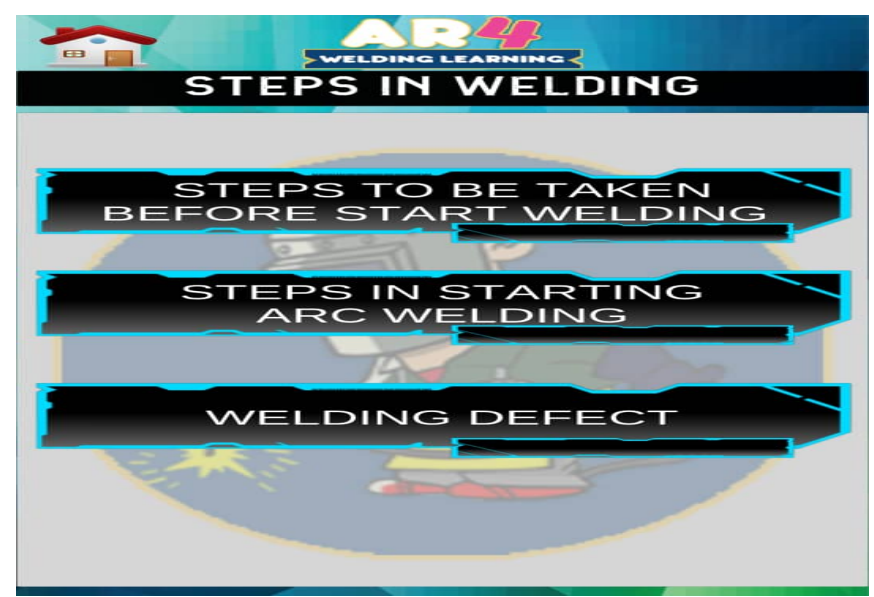

Fig. 4. The interface for steps in welding

The MAWL app has been developed for Android smartphones using Unity 3D and Vuforia. The app is aimed in providing interactive information beyond that of conventional learning approach pertaining to welding. The app incorporates markerbased augmented reality where specific markers are used to activate the virtual objects. Fig. 5 shows two of the markers used for the MAWL app. Each marker consists of an image specifically selected to represent the virtual object that will appear on the smartphone's screen overlapping the actual scene whenever the marker is scanned through the smartphone's camera. Altogether, eight markers will be used in the app. Black and white images were chosen for the markers since they are much easier to be detected under various lighting conditions (Siltanen, 2012). 


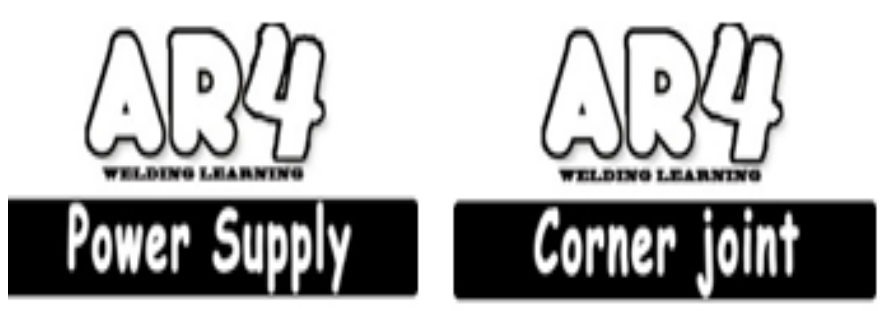

Fig. 5. Sample of MAWL app markers

\section{$4 \quad$ Method}

\subsection{Research model}

The aim of the MAWL app is to provide interactive information through the utilization of mobile learning and augmented reality to students beyond that of conventional welding learning approach. Thus, this study was conducted to evaluate the students' perceptions of the use of the MAWL app in terms of ease of use, engagement, learn ability, satisfaction, usefulness and motivation. The research model for this study is shown in Fig. 6.

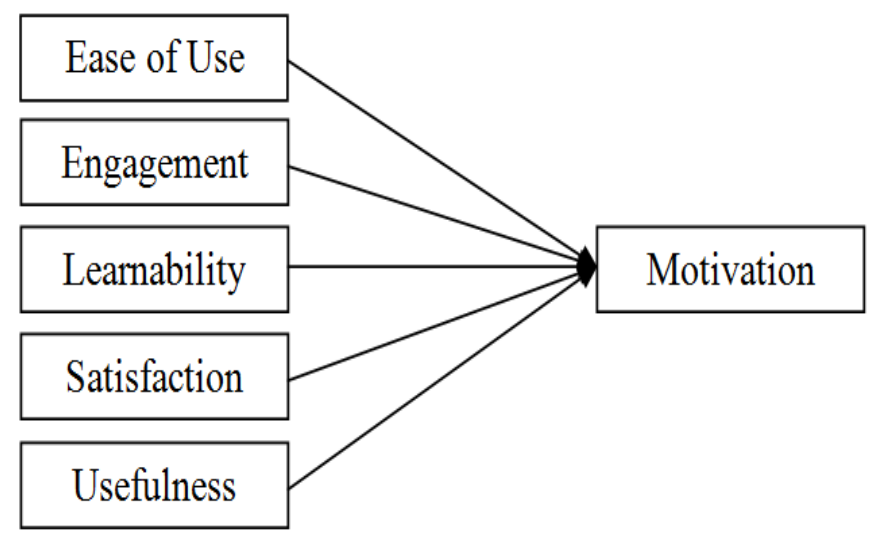

Fig. 6. Research model

\subsection{Participants}

The participants for this evaluation were mechanical engineering students from Politeknik Tuanku Syed Sirajuddin and their ages were between 19 to 20 years old. 67 students participated in this evaluation and the sample size fulfills the minimum 
number requirement as stated by Coakes \& Steed (2007). The samples were selected based on the convenience sampling, a technique of selecting the participants from the population based on accessibility and ease of selection (Groebner, Shannon, Fry, \& Smith, 2013).

\subsection{Instrument}

For the evaluation, a set of questionnaires has been used as an instrument. The instrument was adapted from previous validated instruments and consists of several measurements that include; ease of use, engagement, learn ability, satisfaction, usefulness and motivation. Ease of use is the degree to which a person believes that using a system would be free of effort (Davis, 1989). Perceived ease of use refers to the system whether it is easier to be used, save energy and has the intention to be used repeatedly (Nasution, 2004). Engagement is the degree to which the user has a sense that he/she is deeply involved in the environment (Bierbaum et al., 2001). Learn ability is the degree to which a user believes that using the application would be easy to learn and enhance his/her learning ability (Lin, Choong, \& Salvendy, 1997). Satisfaction is the degree to which a user believes that the possession and/or use of a service evokes positive feelings (Rust \& Oliver, 1994). Usefulness is the degree to which the user believes that using the technology will enhance their performance (Davis, 1989). Lastly, motivation is the degree to which user believes an act that encourages someone to do some action (Guay et al., 2010). The instrument for the evaluation consists of two sections namely; Demographic profile of students and Student's Perception of the use of the Mobile Arc Welding Learning app. A 5-point Likert scale anchored by Strongly Disagree (1) and Strongly Agree (5) was used.

\subsection{Procedure}

Prior to the evaluation, the participants were given a brief explanation about the purpose of the study as well the functions and interfaces of the MAWL app. They were given approximately 15 minutes to answer the questions. After that, the APK of the MAWL app were distributed among the participants in order for them to install the app on their mobile devices. The students were given a week ( 7 days) to use the app to allow them to familiarize with the functions of the app. After a week, the participants were given a set of questionnaires for the purpose of evaluating the participants' perceptions of the use of the MAWL app.

\section{$5 \quad$ Result}

\subsection{Demographic characteristic}

67 mechanical engineering students from semester 1 were chosen as participants for the evaluation. 31 of them were male and another 36 were female. The participants' ages were between 18 to 20 years old. All the participants were studying the welding subject as one of their core courses. 


\subsection{Reliability analysis}

In order to ensure the consistency or stability of the items in an instrument, the reliability analysis was conducted (Sekaran, 2003). The Cronbach alpha $(\alpha)$ scores for all the attributes were calculated using SPSS version 22.0. Table 1 shows the Cronbach alpha scores for all the attributes whereby ease of use has a Cronbach alpha of 0.853 , engagement has a score of 0.829 , learn ability has a score 0.852 , satisfaction has Cronbach alpha of 0.898 , usefulness has a Cronbach alpha of 0.872 and lastly motivation has a Cronbach alpha of 0.877 . Since all the attributes have Cronbach alpha values greater than 0.7 , this proved that all the attributes are reliable (Nunnally, 1978; Hair, 2006).

Table 1. Cronbach Alpha Values for All Attributes

\begin{tabular}{|l|c|c|}
\hline \multicolumn{1}{|c|}{ Attributes } & Number of Items & Cronbach Alpha $\boldsymbol{\alpha}$ \\
\hline Ease Of Use & 6 & 0.853 \\
\hline Engagement & 4 & 0.829 \\
\hline Learnability & 4 & 0.852 \\
\hline Satisfaction & 5 & 0.898 \\
\hline Usefulness & 6 & 0.872 \\
\hline Motivation & 6 & 0.877 \\
\hline
\end{tabular}

\subsection{Descriptive statistics}

In order to understand the users' perceptions toward the use of the MAWL app, the descriptive statistics analysis was conducted to determine the mean and standard deviation scores for each attribute using SPSS version 22.0. Table 2 shows the descriptive statistics for all the items and attributes.

The five-point Likert scale was used as a basis to determine the mean scores for all the attributes and items. However, as suggested by Qasim et al., (2018b), in determining the participants' level of agreement or disagreement with the presented statements, numerical scales are normally used instead of Likert scale. According to Sugiyono (2010), numerical scale is based on measuring the distance between numbers of positions whereby the positions have to be classified into two directional categories (strongly disagree, disagree, strongly agree and agree) without neutral position. Thus, Sugiyono equation was used to calculate the interval range of Likert scales by performing the mathematical equation as follows:

$$
\begin{aligned}
& \mathrm{RS}=(\mathrm{m}-\mathrm{n}) / \mathrm{b} \\
& \text { Whereby; } \\
& \mathrm{RS}=\text { Score range } \\
& \mathrm{m}=\text { highest score on scale } \\
& \mathrm{n}=\text { lowest score on scale } \\
& \mathrm{b}=\text { number of classification } \\
& \mathrm{RS}=(5-1) / 4=1
\end{aligned}
$$

Thus, a numerical scale anchored with 1 to 1.99 for strongly disagree, 2 to 2.99 for disagree, 3 to 3.99 for agree and 4 to 5 for strongly agree was used. Based on the 
numerical scale, the results of the descriptive statistics analysis indicate that the mean scores for ease of use is 4.03 (strongly agree), engagement is 3.93 (agree), learn ability is 4.07 (strongly agree), satisfaction is 4.05 (strongly agree), usefulness is 4.03 (strongly agree) and lastly motivation is 4.01 (strongly agree). The results showed that the participants strongly agreed on ease of use, learn ability, satisfaction, usefulness and motivation and agreed on engagement. Learn ability has the highest mean score of 4.07 while engagement has the lowest mean score of 3.93 .

Table 2. Descriptive Statistics for All Attributes

\begin{tabular}{|c|c|c|}
\hline Attributes and Items & Mean & SD \\
\hline Ease of Use & 4.03 & \\
\hline MAWL was easy to use individually & 4.09 & 0.596 \\
\hline MAWL was suitable for learning about welding & 4.13 & 0.600 \\
\hline MAWL was suitable as a revision tool for welding & 4.10 & 0.606 \\
\hline Augmented Reality was suitable for personal use & 3.87 & 0.694 \\
\hline Steps in using MAWL were easy to remember & 3.93 & 0.611 \\
\hline Augmented Reality has made revision for welding easy & 4.06 & 0.672 \\
\hline Engagement & 3.93 & \\
\hline MAWL attracted me to study welding for a long time & 3.96 & 0.706 \\
\hline MAWL allowed me to review the welding repeatedly & 4.09 & 0.668 \\
\hline MAWL made me to study welding for a long time & 3.73 & 0.898 \\
\hline Mobile Augmented Reality increased my involvement in welding learning & 3.93 & 0.681 \\
\hline Learnability & 4.07 & \\
\hline It was easy to learn to use MAWL & 4.12 & 0.537 \\
\hline Information provided by MAWL was easy to understand & 4.12 & 0.508 \\
\hline Information provided by MAWL helped me in learning welding & 4.12 & 0.537 \\
\hline Using MAWL was reasonable for my study & 3.94 & 0.537 \\
\hline Satisfaction & 4.05 & \\
\hline I was satisfied in using MAWL & 4.03 & 0.651 \\
\hline I was satisfied with the information obtained from MAWL & 4.13 & 0.600 \\
\hline I was satisfied with MAWL's teaching method & 4.09 & 0.596 \\
\hline I was satisfied with the learning environment available on MAWL & 4.04 & 0.589 \\
\hline I was satisfied with the overall effectiveness of learning & 3.94 & 0.672 \\
\hline Usefulness & 4.03 & \\
\hline The use of MAWL allowed me to finish welding learning faster & 4.01 & 0.663 \\
\hline The use of MAWL could improve my learning performance & 4.01 & 0.590 \\
\hline The use of MAWL in welding learning could increase my productivity & 4.07 & 0.586 \\
\hline The use of MAWL could improve the effectiveness of welding learning & 4.00 & 0.651 \\
\hline The use of MAWL made my learning easier & 3.99 & 0.663 \\
\hline I like to learn welding using MAWL & 4.09 & 0.543 \\
\hline Motivation & 4.01 & \\
\hline MAWL was easy to use & 4.09 & 0.596 \\
\hline MAWL enhanced my involvement in welding learning & 4.10 & 0.554 \\
\hline I enjoyed the welding learning for a long time & 3.93 & 0.659 \\
\hline Welding learning becomes more fun by using MAWL & 3.96 & 0.684 \\
\hline MAWL enhanced my motivation to achieve excellence in welding learning & 4.00 & 0.674 \\
\hline $\begin{array}{l}\text { MAWL encouraged me to pursue higher education and careers related to } \\
\text { welding in the future }\end{array}$ & 4.01 & 0.685 \\
\hline
\end{tabular}




\section{Conclusion}

This paper introduced a Mobile Arc Welding Learning (MAWL) app that has been specifically developed for the Mechanical Engineering students of Polytechnic Tuanku Syed Sirajuddin who were learning arc welding as one of their core subjects. The app has been developed as a supplement to the conventional learning approach in the class. This app is intended for the students to learn and understand about arc welding prior to their IBT in the welding workshop. This app provides information related to arc welding through the use of text, image, video and also 3D model. The app has been enhanced with augmented reality aimed at motivating the students to use the app in welding-related learning.

Basically, the app covers topics related to safety in welding, components of welding and steps in welding. It is important to stress on safety since the welding process produces fume which is harmful to welder's health. This paper also elaborates on the user evaluation of the MAWL app. The main purpose of the evaluation is to determine the users' perceptions of the use of the MAWL app as a supplementary learning tool for arc welding. The results of the user evaluation showed that the users strongly agreed on ease of use, learn ability, satisfaction, usefulness and motivation, while they agreed on engagement. The results of this study proved that users are responding well to the use of mobile technology along with augmented reality as a supplementary tool for welding learning. This indicates that mobile augmented reality has the potential to be used more widely in Technical and Vocational Education and Training as it involves not only theoretical learning but also combined with practical works.

\section{$7 \quad$ Acknowledgment}

Our deepest gratitude goes to the Universiti Utara Malaysia for supporting us by funding this research and also for other supports and facilities provided that has facilitated the research process along this year.

\section{References}

[1] Abachi, H. R., \& Muhammad, G. (2014). The impact of m-learning technology on students and educators. Computers in Human Behavior, 30, 491-496. https://doi.org/10.10 16/j.chb.2013.06.018

[2] Al-Hasnawi, S., Ahmad, M., Al-Janabi, A., Zulkifli, A. N., Omar, M., \& Bakar, J. A. A. (2016). Design of Mobile Healthcare Reminder for Chronic Diabetes. Journal of Telecommunication, Electronic and Computer Engineering (JTEC), 8(8), 61-64.

[3] Ali, D. F., Johari, N., \& Omar, M. (2017). Augmented Reality Mobile Learning Apps (ARMLAApps). University Carnival on E-Learning (IUCEL) 2017, 96.

[4] Astro Awani (2017). Kerajaan isytihar 2017 tahun TVET. Retrieved from http://www.astroawani.com/berita-malaysia/kerajaan-isytihar-2017-tahun-tvet-riot-130341 
[5] Astro Awani (2018, Novermber 2). TVET, IPT terus mendapat perhatian dalam Belanjawan 2019. Astro Awani. Retrieved from http://www.astroawani.com/beritamalaysia/tvet-ipt-terus-mendapat-perhatian-dalam-belanjawan-2019-190057

[6] Berita Harian Online (2018, November 2). Ucapan Pembentangan Belanjawan 2019. BH Online. Retrieved from https://www.bharian.com.my/berita/nasional/2018/11/493776/ucapan-pembentanganbelanjawan-2019

[7] Bidin, S., \& Ziden, A. A. (2013). Adoption and application of mobile learning in the education industry. Procedia-Social and Behavioral Sciences, 90, 720-729. https://doi.org/10.1016/j.sbspro.2013.07.145

[8] Bierbaum, A., Just, C., Hartling, P., Meinert, K., Baker, A., \& Cruz-Neira, C. (2001, March). VR Juggler: A virtual platform for virtual reality application development. In Proceedings IEEE Virtual Reality 2001 (pp. 89-96). IEEE.

[9] Billinghurst, M., \& Dünser, A. (2012). Augmented reality in the classroom. Computer, 45(7), 56-63. https://doi.org/10.1109/MC.2012.111

[10] Burguillo, J.C. (2010). Using game theory and competition-based learning to stimulate student motivation and performance, Comp. \& Educ. 55(2), 566-575. https://doi.org/10.1016/j.compedu.2010.02.018

[11] Camilleri, M.A. and Camilleri, A.C. 2017. Digital learning resources and ubiquitous technologies in education. Tech .Knowl. and Learning, 22(1), 65-82. https://doi.org/10.1007/s10758-016-9287-7

[12] Carvalho, M.B., Bellotti, F., Berta, R., De Gloria, A., Sedano, C.I., Hauge, H.B., Hu, J. and Rauterberg, M. (2015). An activity theory-based model for serious games analysis and conceptual design," Computers \& Education. 87, 166-181. https://doi.org/10.1016 j.compedu.2015.03.023

[13] Cheng, K. H., \& Tsai, C. C. (2013). Affordances of augmented reality in science learning: Suggestions for future research. Journal of science education and technology, 22(4), 449462. https://doi.org/10.1007/s10956-012-9405-9

[14] Coakes, S. J. (2007). Analysis without anguish: Version 12.0 for Windows. John Wiley \& Sons, Inc.

[15] Connolly, T.M., Boyle, E.A., MacArthur, E. Hainey, T. and Boyle, J.M. 2012. A systematic literature review of empirical evidence on computer games and serious games," Comp. \& Educ. 59(2), 661-686. https://doi.org/10.1016/j.compedu.2012.03.004

[16] Crookall, D. 2010. Serious games, debriefing, and simulation/gaming as a discipline, Sim. \& Gaming. 41(6), 898-920. https://doi.org/10.1177/1046878110390784

[17] Davis, F. D. (1989). Perceived usefulness, perceived ease of use, and user acceptance of information technology. MIS quarterly, 319-340. https://doi.org/10.2307/249008

[18] Dickey, M.D. (2011). Murder on Grimm Isle: The impact of game narrative design in an educational game-based learning environment, Brit. J. of Educ. Tech. 42(3), 456-469. https://doi.org/10.1111/j.1467-8535.2009.01032.x

[19] Diegmann, P., Schmidt-Kraepelin, M., Eynden, S., \& Basten, D. (2015). Benefits of augmented reality in educational environments-a systematic literature review. Benefits, 3(6), 1542-1556.

[20] Ebner, M. and Holzinger, A. (2007). Successful implementation of user-centered gamebased learning in higher education: An example from civil engineering, Computer \& Education, 49(3), 873-890. https://doi.org/10.1016/j.compedu.2005.11.026

[21] Economic Transformation Plan (2014). http://etp.pemandu.gov.my/annualreport2014/. Retrieved 30 June 2017. 
[22] Free Malaysia Today (2018, October 5). Bajet pendidikan 2019 fokus infrastruktur sekolah, tingkat TVET, kata Maszlee. FMT News. Retrieved from https://www.freemalaysiatoday.com/category/bahasa/2018/10/05/bajet-pendidikan-2019fokus-infrastruktur-sekolah-tingkat-tvet-kata-maszlee/

[23] Ge, X. and Ifenthaler, D. 2018. Designing engaging educational games and assessing engagement in game-based learning" In Gamification in Education: Breakthroughs in Research and Practice, 1-19, IGI Global, Hershey, USA. https://doi.org/10.4018/978-15225-5198-0.ch001

[24] Gopalan, V., Bakar, J. A. A., Zulkifli, A. N., \& Alwi, A. (2018). A Review of Augmented Multimedia Elements in Science Learning. Journal of Telecommunication, Electronic and Computer Engineering (JTEC), 10(1-10), 87-92.

[25] Gopalan, V., Zulkifli, A. N., Mohamed, N. F. F., Alwi, A., Mat, R. C., Bakar, J. A. A., \& Saidin, A. Z. (2015). Evaluation of e-STAR: an enhanced science textbook using Augmented Reality among lowers secondary school students. Jurnal Teknologi, 77(29). https://doi.org/10.11113/jt.v77.6813

[26] Groebner, D. F., Shannon, P. W., Fry, P. C., \& Smith, K. D. (2013). Business statistics. Pearson Education UK.

[27] Guay, F., Chanal, J., Ratelle, C. F., Marsh, H. W., Larose, S., \& Boivin, M. (2010). Intrinsic, identified, and controlled types of motivation for school subjects in young elementary school children. British Journal of Educational Psychology, 80(4), 711-735. https://doi.org/10.1348/000709910X499084

[28] Hadiwardoyo, S. A., Patra, S., Calafate, C. T., Cano, J. C., \& Manzoni, P. (2018). An intelligent transportation system application for smartphones based on vehicle position advertising and route sharing in vehicular ad-hoc networks. Journal of Computer Science and Technology, 33(2), 249-262. https://doi.org/10.1007/s11390-018-1817-4

[29] Hair, J. F. (2006). Multivariate data analysis. Prentice Hall, New Jersey.

[30] Hashimoto, N. (2015). Difference of Improving Welder's Skill through Training Progression. Bulletin of Hiroshima Institute of Technology Research, 49, 75-81.

[31] Hwang, G.J. and Wu, P.H. (2012). Advancements and trends in digital game- based learning research: a review of publications in selected journals from 2001 to 2010," Brit. J. of Educ. Tech. 43(1), E6- E10. https://doi.org/10.1111/j.1467-8535.2011.01242.x

[32] Idris, H., Zulkifli, A. N. \& Yusoff, M. F. (2018). Mobile Augmented Reality in Advertising for Printed Media Microenterprise. Journal of Advanced Research in Dynamical \& Control Systems, 10(10), 1493-1500

[33] Ismail, A., \& Abiddin, N. Z. (2014). Issues and challenges of Technical and Vocational Education and Training in Malaysia towards human capital development. Middle-East Journal of Scientific Research, 19(2), 7-11.

[34] Kementerian Pendidikan Malaysia (2012). Preliminary Report Malaysia Education Blueprint 2013-2025. Retrieved November, 4, 2012.

[35] Kerawalla, L., Luckin, R., Seljeflot, S., \& Woolard, A. (2006). "Making it real": exploring the potential of augmented reality for teaching primary school science. Virtual reality, 10(3-4), 163-174. https://doi.org/10.1007/s10055-006-0036-4

[36] Lee, K. (2012). Augmented reality in education and training. TechTrends, 56(2), 13-21. https://doi.org/10.1007/s11528-012-0559-3

[37] Leong, P. C. (2011). Key reforms in revitalising technical and vocational education and training (TVET) in Malaysia. In Regional Conference on Human Resource Development Through TVET as a Development Strategy in Asia (pp. 4-5). 
[38] Lin, H. X., Choong, Y. Y., \& Salvendy, G. (1997). A proposed index of usability: a method for comparing the relative usability of different software systems. Behaviour \& information technology, 16(4-5), 267-277. https://doi.org/10.1080/014492997119833

[39] Lugmayr, A., Sutinen, E., Suhonen, J., Sedano, C.I., Hlavacs, H., and Montero, C.S. 2017. Serious storytelling-a first definition and review, Multimedia Tools and Applic.. 76(14), 15707-15733. https://doi.org/10.1007/s11042-016-3865-5

[40] Mahamad, S., Ibrahim, M.N., \& Taib, S.M. (2010). M-learning: A new paradigm of learning mathematics in Malaysia, International Journal of Computer Science \& Information Technology, 2(4), 76-86. https://doi.org/10.5121/ijcsit.2010.2407

[41] McMillan, K., Flood, K., \& Glaeser, R. (2017). Virtual reality, augmented reality, mixed reality, and the marine conservation movement. Aquatic Conservation: Marine and Freshwater Ecosystems, 27, 162-168. https://doi.org/10.1002/aqc.2820

[42] Nasution, F. N. (2004). Penggunaan teknologi informasi berdasarkan aspek perilaku (Behavioral aspect). USU digital library. Retrieved from http://repository.usu. ac.id/handle/123456789/1194.

[43] Natarajan, V. (2016). 50 Years of Technical Education in Singapore: How to Build a World Class TVET System. World Scientific.

[44] Ngure, S. W. (2013). Where to vocational education in Kenya? Is analysing training and development needs the answer to the challenges in this sector? Journal of Education and Vocational Research, 4(6), 193-204.

[45] Nunnally, J. C. (1978). Psychometric theory. McGraw-Hill, New York.

[46] Nyerere, J. (2009). Technical and Vocational Education and Training (TVET) sector mapping in Kenya. Amersfoort: Edukans Foundation.

[47] O'bannon, B. W., \& Thomas, K. (2014). Teacher perceptions of using mobile phones in the classroom: Age matters! Computers \& Education, 74, 15-25. https://doi.org/10. 1016/j.compedu.2014.01.006

[48] Okimoto, M. L. L., Okimoto, P. C., \& Goldbach, C. E. (2015). User experience in augmented reality applied to the welding education. Procedia Manufacturing, 3, 62236227. https://doi.org/10.1016/j.promfg.2015.07.739

[49] Oz, C., Ayar, K., Serttas, S., Iyibilgin, O., Soy, U., \& Cit, G. (2012). A Performance Evaluation Application for Welder Candidate in Virtual Welding Simulator. ProcediaSocial and Behavioral Sciences, 55, 492-501. https://doi.org/10.1016/j.sbspro.2012.09.529

[50] Ozdamli, F., \& Cavus, N. (2011). Basic elements and characteristics of mobile learning. Procedia-Social and Behavioral Sciences, 28, 937-942. https://doi.org/10. 1016/i.sbspro.2011.11.173

[51] Qasim, M. M., Ahmad, M., Omar, M., Zulkifli, A. N., \& Abu Bakar, J. A. (2018a). Persuasive Technology and Mobile Healthcare: A Critical Review. Journal of Advanced Research in Dynamical \& Control Systems, 10(10), 1501-1513.

[52] Qasim, M. M., Ahmad, M., Omar, M., Zulkifli, A. N., \& Abu Bakar, J. A. (2015). Parents' Perception towards the Adoption of Mobile Application for Monitoring Their Children's Obesity Status. ARPN Journal of Engineering and Applied Sciences, 10(3), 977-985.

[53] Qasim, M. M., Ahmad, M., Omar, M., Zulkifli, A. N., \& Abu Bakar, J. A. (2018b). A process for developing an instrument to measure the persuasion perspectives of parents using PMCOM app. In AIP Conference Proceedings (Vol. 2016, No. 1, p. 020119). AIP Publishing. https://doi.org/10.1063/1.5055521

[54] Ramya, G., \& Madhumathi, P. (2017). Adopting Augmented Reality for English Language Teaching and Learning. Language in India, 17(7).

[55] Rust, R.T. and Oliver, R.L. (1994), Service Quality: New Directions in Theory and Practice, Sage Publications, Thousand Oaks, CA. 
[56] Sandholtz, J.H. 1997. Teaching with technology: Creating student-centered classrooms. Teachers College Press, New York, USA.

[57] Sanusi, A. N. Z., Abdullah, F., Kassim, M. H., \& Tidjani, A. A. (2018). Architectural History Education: Students' Perception on Mobile Augmented Reality Learning Experience. Advanced Science Letters, 24(11), 8171-8175. https://doi.org/10. $\underline{1166 / \text { asl.2018.12517 }}$

[58] Sekaran U. (2003). Research methods for business: A skill-building approach, John Wiley \& Sons, Inc., (2003).

[59] Shamsuddin, A., Wahab, E., Abdullah, N. H., \& Suratkon, A. (2018, November). Mobile Learning Adoption in Enhancing Learning Experience Among HEI students. In 2018 IEEE 10th International Conference on Engineering Education (ICEED) (pp. 202-207). IEEE. https://doi.org/10.1109/ICEED.2018.8626923

[60] Siltanen, S. (2012). Theory and applications of marker-based augmented reality. VTT.

[61] Sing, L. L., \& Annie, K. (2018). An Interactive Smart e-Learning System on Technical Vocational Education and Training (TVET) in Malaysia using Augmented Reality Technology. University Carnival on E-Learning (IUCEL) 2018, 278.

[62] Sugiyono P., Metode Penelitian Kuantitatif, Kualitatif dan R\&D (Qualitative and Quantitative Research Methods), Alfabeta, (2010).

[63] Suprianto, A., Ahmadi, F., \& Suminar, T. (2019). The Development of Mathematics Mobile Learning Media to Improve Students' Autonomous and Learning Outcomes. Journal of Primary Education, 8(1), 84-91.

[64] The Star Online (2016, October 2). TVET skills equip youth for jobs. Star Online. Retrieved from http://www.thestar.com.my/news/education/2016/10/02/tvet-skills-equipyouth-for-jobs/

[65] The Sundaily (2015, May 21). 11MP: $60 \%$ of $1.5 \mathrm{~m}$ jobs created by 2020 to require TVETrelated skills. The Sundaily. Retrieved from http://www.thesundaily.my/news/1426473

[66] Tripney, J. S., \& Hombrados, J. G. (2013). Technical and vocational education and training (TVET) for young people in low-and middle-income countries: a systematic review and meta-analysis. Empirical Research in Vocational Education and Training, 5(1), 3. https://doi.org/10.1186/1877-6345-5-3

[67] UNESCO. (2004). Normative instruments concerning technical and vocational education. United Nations Educational, Scientific and Cultural Organization, Paris.

[68] Viberg, O., \& Grönlund, Å. (2013). Cross-cultural analysis of users' attitudes toward the use of mobile devices in second and foreign language learning in higher education: A case from Sweden and China. Computers \& Education, 69, 169-180. https://doi.org/10.101 6/j.compedu.2013.07.014

[69] Wang, Y., Chen, Y., Nan, Z., \& Hu, Y. (2006, December). Study on welder training by means of haptic guidance and virtual reality for arc welding. In 2006 IEEE international conference on robotics and biomimetics (pp. 954-958). IEEE. https://doi.org/10. 1109/ROBIO.2006.340349

[70] Wouters, P. Van Nimwegen, C. Van Oostendorp, H. and Van Der Spek, E.D. 2013. A meta-analysis of the cognitive and motivational effects of serious games, J. of Educ. Psych. 105(2), 249-266. https://doi.org/10.1037/a0031311

[71] Yahya, F. F., Abas, H. A. F. I. Z. A., \& Yussof, R. L. (2018). Integration of screencast video through $\mathrm{QR}$ Code: An effective learning material for m-Learning. Journal of Engineering Science and Technology, 1-13.

[72] Yang, S., \& Mei, B. (2018). Understanding learners' use of augmented reality in language learning: insights from a case study. Journal of Education for Teaching, 44(4), 511-513. https://doi.org/10.1080/02607476.2018.1450937 
[73] Zelloth, H. (2014). Career guidance for Vocational Education and Training (VET). Journal of the National Institute for Career Education and Counselling, 33(1): 49-55.

[74] Zulkifli, A. N., Alnagrat, A. J. A., \& Mat, R. C. (2016). Development and evaluation of iBrochure: A mobile augmented reality application. Journal of Telecommunication, Electronic and Computer Engineering (JTEC), 8(10), 145-150.

\section{Authors}

Farhatun Najwa Rusli is a Master of Multimedia Studies (by research) student at the School of Multimedia Technology and Communication, Universiti Utara Malaysia. Her research interests include Mobile Augmented Reality, Technical and Vocational Education, human-computer interaction and mobile application.

Email id: najwarusli.18@gmail.com

Abdul Nasir Zulkifli is an Associate Professor at the School of Creative Industry Management and Performing Arts, Universiti Utara Malaysia. He has been a lecturer at the Universiti Utara Malaysia since 1999 and his research interests include Augmented Reality, Virtual Reality, persuasive application, Technical and Vocational Education, human-computer interaction, mobile application, museum study and cultural heritage.

Mohd. Nizam bin Saad is a senior lecturer at the School of Multimedia Technology and Communication, Universiti Utara Malaysia. His research domain is in the medical image processing. In his doctoral research project, he formed a new model for medical image annotation. He also likes to explore human-computer interaction research especially on improving usability features. He has wide experience in conducting usability study specifically using expert review via cognitive walk-through technique.

Yussalita Md. Yussop is a lecturer at the School of Multimedia Technology and Communication, Universiti Utara Malaysia. She has been a lecturer at the Universiti Utara Malaysia since 1999 and her research interests include multimedia, humancomputer interaction and mobile application.

Article submitted 2019-06-21. Resubmitted 2019-07-14. Final acceptance 2019-07-27. Final version published as submitted by the authors. 